\title{
ANALISIS DAMPAK PENGELOLAAN PERTAMBANGAN NIKEL TERHADAP PENYERAPAN TENAGA KERJA LOKAL DI KABUPATEN KONAWE UTARA
}

\author{
Burhan \\ Magister Ilmu Ekonomi Program Pascasarjana Universitas Halu Oleo \\ Email: burhan.konut@gmail.com \\ Rosnawintang \\ Fakultas Ekonomi dan Bisnis Universitas Halu Oleo \\ Email: nanarosnawintang@gmail.com \\ Wali Aya Rumbia \\ Fakultas Ekonomi dan Bisnis Universitas Halu Oleo \\ Email: waliayaunhalu@gmail.com
}

\begin{abstract}
ABSTRAK
Tujuan penelitian ini yaitu menganalisis dampak pengelolaan tambang terhadap penyerapan tenaga kerja lokal di Kabupaten Konawe Utara . Populasi dalam penelitian ini adalah masyarakat yang bekerja di tambang nikel di Kabupaten Konawe Utara yang berjumlah 126 orang. Adapun Sampel yang digunakan dalam penelitian ini didapat dengan teknik pengambilan sampel (teknik sampling) Nonprobability Sampling dengan Rumus Slovin. Data yang digunakan data sekunder dan primer. Analisis data menggunakan regresi linear sederhana dengan bantuan software SPSS versi 24 . Hasil penelitian menunjukkan bahwa pengelolaan tambang nikel berpengaruh signifikan dan positif terhadap penyerapan tenaga kerja lokal di Kabupaten Konawe Utara.
\end{abstract}

Kata Kunci: Pengelolaan Tambang Nikel, Penyerapan Tenaga Kerja.

\section{ABSTRACT}

The purpose of this study is to analyze the impact of mine management on the absorption of local labor in North Konawe Regency. The population in this study was people working in nickel mines in North Konawe Regency which amounted to 126 people. The samples used in this study were obtained by sampling techniques (sampling techniques) Nonprobability Sampling with Slovin Formula. Data used secondary and primary data. Analyze data using simple linear regression with the help of SPSS version 24 software. The results showed that the management of nickel mines had a significant and positive effect on the absorption of local labor in North Konawe Regency.

Keywords: Nickel Mine Management, Labor Absorption.

\section{PENDAHULUAN}

Indonesia merupakan negara yang kaya dengan sumberdaya alam. Sumberdaya alam (baik renewable dan non renewable) merupakan sumberdaya yang esensial bagi kelangsungan hidup manusia. Pengelolaan dan penguasaan sumber daya alam telah dibangun melalui semangat UUD 1945 Pasal 33 dengan tujuan utama adalah untuk sebesarbesarnya kemakmuran bagi rakyat Indonesia. Amanat UUD 1945 ini merupakan landasan pembentukan kebijakan pertambangan yakni UU No 11 Tahun 1967 tentang pokok pertambangan mineral dan batubara yang kemudian diganti dengan Undang-Undang Nomor 4 Tahun 2009 tentang Pertambangan Mineral dan Batubara.

Ketentuan lain bijih nikel sebagai salah satu sumber daya alam dalam industri pertambangan karena dipandang memberikan pendapatan asli daerah yang lebih tinggi sehingga dapat meningkatkan perekonomian dan pembangunan, serta menciptakan lapangan kerja bagi masyarakat lokal dan masyarakat luar lokasi penambangan. Selain itu, karena beberapa industry memiliki modal berupa teknologi tinggi, diharapkan mampu mengelola sumber daya mineral dengan baik dan efisien. Namun 
Jurnal Progres Ekonomi Pembangunan (JPEP)

Volume 6, Nomor 2. Tahun 2021

Page: 110 - 122

http://ojs.uho.ac.id/index.php/JPEP

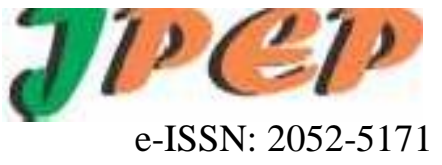

dalam implementasinya, pengelolaan sumber daya mineral oleh industri tidak selalu berjalan dengan baik, contohnya tambang nikel di Kabupaten Konawe Utara.

Kemudian fenomena yang terjadi penyerapan tenaga kerja pada tambang nikel di Kabupaten Konawe Utara yang sering terjadi adalah adanya konflik antara tenaga kerja lokal dan tenaga kerja asing, dalam sistem perekrutan tenaga kerja yang memiliki skill (keterampilan) lebih diutamakan dari tenaga kerja asing. Sedangkan tenaga kerja lokal hanya bekerja sebagai tenaga kerja harian atau buruh. Kemudian aktivitas tambang nikel di Kabupaten Konawe Utara menimbulkan kerusakan lingkungan muncul diakibatkan karena perusahaan pertambangan tidak memperhatikan lingkungan dalam melakukan kegiatan.

Kemudian untuk menguji dampak pengelolaan tambang terhadap penyerapan tenaga kerja, mengacu pada undang-undang Nomor 13 Tahun 2003 tentang Tenaga Kerja memberikan pengertian tentang tenaga kerja yang terdapat dalam Pasal 1 ayat 2 bahwa tenaga kerja yaitu setiap orang yang mampu melakukan pekerjaan guna menghasilkan barang dan/atau jasa baik untuk memenuhi kebutuhan sendiri maupun untuk masyarakat. Penyerapan tenaga kerja merupakan penduduk yang mampu bekerja dalam usia kerja (15-64 tahun) yang terdiri dari orang yang mencari kerja, punya pekerjaan namun sementara tidak bekerja atau menganggur. (Kuncoro, 2012, dan Putra, 2012). Sedangkan Menurut UU No 13 Tahun 2003 tentang ketenagakerjaan, tenaga kerja adalah setiap orang yang mampu melakukan pekerjaan guna menghasilkan barang dan jasa baik untuk memenuhi kebutuhan sendiri maupun untuk masyarakat.

Pandangan mikro merupakan pandangan yang tidak hanya menyumbangkan potensi kerja namun dengan kerja mampu menerima imbalan berupa barang atau uang. Sedangkan secara makro adalah setiap orang yang mampu memenuhi kebutuhan masyakarat sebagai upaya dalam menghasilkan barang dan jasa (Mankiw, 2010). Penyerapan tenaga kerja yang dilakukan merupakan jumlah tenaga kerja yang diserap dalam usaha tertentu. Namun kemampuan penyerapan akan berbeda satu unit usaha dengan usaha lainnya karena kemampuan unit usaha yang berbeda-beda. (Indayati, $2010 \mathrm{dkk})$.

Hasil penelitian terdahulu yang telah membuktikan bahwa dampak pengelolaan tambang terhadap penyerapan tenaga kerja dilakukan oleh Diana Lestari (2016), dan Candra Mustika (2018), yang menyatakan bahwa sektor pertambangan berpengaruh signifikan dan positif terhadap penyerapan tenaga kerja. Namun, masih terdapat kontradiksi hasil penelitian yang dilakukan oleh Zamzami, Candra Mustika dan Jaya Kesuma Edy (2015) yang menyatakan bahwa sektor pertambangan tidak berpengaruh signifikan terhadap penyerapan tenaga kerja. Faktor pembentuk variabel penyerapan tenaga kerja yang menjadi landasan pengembangan alat ukur dalam penelitian ini berasal dari konsep yang dikemukakan oleh Barthos (1999), yaitu; 1) tenaga kerja fisik dan 2) tenaga kerja berdasarkan pikiran. Penelitian ini bertujuan untuk menganalisis dampak pengelolaan tambang nikel terhadap penyerapan tenaga kerja lokal di Kabupaten Konawe Utara.

\section{TINJAUAN PUSTAKA DAN KERANGKA KONSEP \\ Konsep Pengelolaan Pertambangan \\ Definsi Pengelolaan Pertambangan}

Menurut UU 4/2009 tentang Pertambangan Mineral dan Batubara Izin Usaha Pertambangan (IUP) adalah izin untuk melaksanakan usaha pertambangan, yang dapat diberikan kepada badan usaha, koperasi ataupun perorangan. IUP diberikan melalui tahapan pemberian Wilayah Izin Usaha Pertambangan (WIUP), IUP Eksplorasi dan IUP Operasi Produksi. Dalam pelaksanaan pengelolaan lingkungan diperlukan upaya pembinaan dan pengawasan dari pemerintah agar pengelolaan dan pelaksanaan kegiatan usaha pertambangan dapat memberikan manfaat yang optimal bagi berlangsungnya pembangunan yang berkelanjutan. Peratuan Pemerintah (PP) 55 Tahun 2010 tentang Pembinaan dan Pengawasan Penyelenggaraan Pengelolaan Usaha Pertambangan Mineral dan Batubara menyatakan bahwa Pembinaan dan pengawasan bidang lingkungan merupakan tanggung jawab pemerintah yang diwujudkan melalui peranan Inspektur Tambang (IT). 
Jurnal Progres Ekonomi Pembangunan (JPEP)

Volume 6, Nomor 2. Tahun 2021

Page: 110 - 122

http://ojs.uho.ac.id/index.php/JPEP

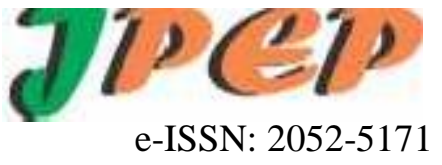

Inspektur Tambang bertanggung jawab melakukan pembinaaan terhadap pelaku usaha pertambangan sehingga setiap aktivitasnya selalu disertai dengan tindakan pencegahan terhadap potensi terjadinya kerusakan lingkungan. Melalui pengawasan dapat dipastikan kegiatan setiap pelaku usaha pertambangan berjalan sesuai dengan aturan yang berlaku (Firmanto, 2012). Pertambangan adalah suatu kegiatan yang dilakukan dengan penggalian ke dalam tanah (bumi) untuk mendapatkan sesuatu yang berupa hasil tambang (Gatot, 2012). Istilah Izin Usaha Pertambangan yang selanjutnya disebut IUP berasal dari terjemahan bahasa inggris, yaitu mining permit (Salim, 2012).

Definisi IUP menurut Pasal 1 angka 7 Undang-undang Nomor 4 Tahun 2009 adalah izin untuk melaksanakan usaha pertambangan. Namun dengan adanya Undang-undang Nomor 23 Tahun 2014 tentang Pemerintah Daerah, maka yang berwenang memberikan Izin Usaha Pertambangan adalah Pemerintah Provinsi sesuai dengan kewenangan yang dimilikinya. Prinsip pemberian IUP yang diatur di dalam Undang-undang Nomor 4 Tahun 2009 merupakan salah satu IUP hanya diperbolehkan untuk satu jenis tambang. Satu IUP diberikan untuk satu jenis mineral atau batubara. Pemberian IUP tidak boleh lebih dari satu jenis tambang (Gatot 2012). IUP dikenal ada dua macam yaitu IUP Eksplorasi dan IUP Operasi Produksi, yang penerbitan izinnya dilakukan secara bertahap yaitu IUP Eksplorasi IUP Operasi Produksi

\section{Indikator Pengelolaan Pertambangan}

Tahap-tahap dalam aktivitas penambangan modern ada empat macam, antara lain sebagai berikut (Hartman, 1987 dalam Latupono, 2005).

1) Prospecting, bertujuan untuk mencari bahan tambang yang mempunyai nilai jual (mineral logam atau non logam).

2) Exploration, bertujuan untuk mendeterminasi keakuratan cadangan bahan tambang. Pada tahap ini dilakukan studi kelayakan.

3) Development, merupakan tahap pembukaan deposit bahan tambang untuk tahap selanjutnya yaitu produksi, pada tahap ini dilakukan: a) penghentian kegiatan jika pada tahap 2 (tahap ekplorasi) tidak layak tambang; b) studi dampak lingkungan, teknologi yang sesuai, serta perijinan; c) konstruksi akses jalan dan system transportasi; d) penentuan lokasi pabrik dan fasilitas konstruksi; e) pembukaan lahan bahan tambang.

4) Eksploitation, merupakan tahap produksi bahan tambang.

Penambangan adalah kegiatan yang memiliki kecenderungan untuk menurunkan nilai dan mutu lingkungan. Usaha pemerintah untuk menekan terjadinya penurunan kualitas lingkungan akibat aktivitas penambangan adalah dengan mengeluarkan beberapa peraturan, peraturan tersebut diantaranya adalah Undang-Undang Nomor 32 tahun 2009 tentang Perlindungan dan Pengelolaan Lingkungan Hidup dan Keputusan Menteri Lingkungan Hidup Nomor 17 Tahun 2001 tentang Jenis Rencana Usaha dan atau Kegiatan yang wajib dilengkapi dengan AMDAL.

Kegiatan pertambangan berdampak pada lingkungan, baik skala besar maupun skala kecil. Pada pertambangan berskala besar, dampak dapat terjadi sejak tahap eksplorasi hingga eksploitasi. Berdasarkan kegiatan dan efek dampak yang ditimbulkannya, maka dampak tersebut tersebut di atas harus dikelola dan ditekan menjadi semenimal munkin, dengan kondisi lingkungan segera dipulihkan kembali. Upaya Pengelolaan lingkungan adalah serangkaian kegiatan/upaya terpadu untuk melestarikan fungsi lingkungan hidup yang meliputi kebijakan pelaksanan, pengembangan, pemeliharan, pemulihan, pengawasan, dan pengendalian lingkungan hidup, termasuk pula bagi pengelolaan kehayati dibidang pertambangan (Direktorat Teknik dan Lingkungan Mineral Batubara dan Panas Bumi, 2006) Industri pertambangan merupakan industri yang penuh dengan kontroversi.

\section{Konsep Penyerapan Tenaga Kerja}

Keberhasilan suatu pembangunan ekonomi dipengaruhi oleh faktor produksi. Faktor produksi sering didefinisikan sebagai setiap hal yang diperlukan secara teknis untuk memproduksi suatu barang atau jasa. Faktor-faktor produksi tersebut diantaranya yaitu bahan pokok peralatan gedung, tenaga kerja, mesin dan modal yang secara garis besar dapat dikategorikan menjadi input manusia dan non 
Jurnal Progres Ekonomi Pembangunan (JPEP)

Volume 6, Nomor 2. Tahun 2021

Page: 110 - 122

http://ojs.uho.ac.id/index.php/JPEP

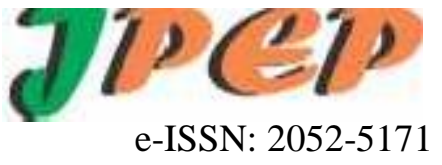

manusia. Dalam Undang-Undang Nomor 13 Tahun 2003 tentang Tenaga Kerja memberikan pengertian tentang tenaga kerja yang terdapat dalam Pasal 1 ayat 2 bahwa tenaga kerja yaitu setiap orang yang mampu melakukan pekerjaan guna menghasilkan barang dan/atau jasa baik untuk memenuhi kebutuhan sendiri maupun untuk masyarakat.

Penyerapan tenaga kerja merupakan penduduk yang mampu bekerja dalam usia kerja (15-64 tahun) yang terdiri dari orang yang mencari kerja, punya pekerjaan namun sementara tidak bekerja atau menganggur. (Kuncoro, 2012, dan Putra, 2012). Sedangkan menurut UU No 13 Tahun 2003 tentang ketenagakerjaan, tenaga kerja adalah setiap orang yang mampu melakukan pekerjaan guna menghasilkan barang dan jasa baik untuk memenuhi kebutuhan sendiri maupun untuk masyarakat. Pengertian tenaga kerja dapat dilihat secara mikro dan makro. Pandangan mikro merupakan pandangan yang tidak hanya menyumbangkan potensi kerja namun dengan kerja mampu menerima imbalan berupa barang atau uang. Sedangkan secara makro adalah setiap orang yang mampu memenuhi kebutuhan masyakarat sebagai upaya dalam menghasilkan barang dan jasa (Mankiw, 2010).

Penyerapan tenaga kerja yang dilakukan merupakan jumlah tenaga kerja yang diserap dalam usaha tertentu. Namun kemampuan penyerapan akan berbeda satu unit usaha dengan usaha lainnya karena kemampuan unit usaha yang berbeda-beda. (Indayati, 2010 dkk). Menurut Kuncoro (2002) penyerapan tenaga kerja merupakan banyaknya lapangan kerja yang sudah terisi yang tercermin dari banyaknya jumlah penduduk bekerja. Penyerapan tenaga kerja bisa di kaitkan dengan keseimbangan interaksi antara permintaan tenaga kerja dan penawaran tenaga kerja, yang di mana permintaan tenaga kerja pasar dan penawaran tenaga kerja pasar secara bersama menentukan suatu penggunaan tenaga kerja keseimbangan (Fuad dan Kandung, 2013). Menurut BPS (2001) yang tergolong dalam kelompok angkatan kerja yaitu mereka yang termasuk usia kerja selama seminggu yang lalu mempunyai pekerjaan, baik yang bekerja maupun sementara tidak bekerja dikarenakan suatu alasan tertentu, contohnya pegawai yang sedang mengambil cuti maupun petani yang menunggu masa panen.

Menurut Todaro (2003), penyerapan tenaga kerja merupakan penerimaan tenaga kerja untuk melakukan tugas (pekerjaan) atau suatu keadaan yang mengggambarkan tersedianya lapangan pekerjaan untuk siap diisi oleh para pencari pekerjaan. Secara umum, penyerapan tenaga kerja tersebut menunjukkan seberapa besar suatu perusahaan dalam menyerap tenaga kerja untuk menghasilkan suatu produk. Kemampuan untuk menyerap tenaga kerja berbeda dari satu sektor dengan sektor lainnya. Sumarsono, (2003).

\section{Hubungan Antara Pengelolaan Pertambangan Terhadap Penyerapan Tenaga Kerja}

Sektor industri mempunyai peranan penting dalam tata perekonomian nasional dimana selain dapat meningkatkan pendapatan Negara, sektor industri juga dapat memberikan kesempatan baru dalam berusaha yang memberi kontribusi positif dalam upaya pemerataan kesejahteraan masyarakat. Olehnya itu pembangunan industri dalam suatu wilayah harus dipertimbangkan sebaik-baiknya yang dimana secara garis besarnya adalah pertimbangan dari segi ekonomis dan pertimbangan non ekonomis. Dipandang dari sudut ekonomi, keberadaan suatu industri pertambangan dalam suatu wilayah akan memberikan dampak terhadap perkembangan wilayah yang akan memberi peluang dan upaya perluasan kesempatan kerja, peningkatan pendapatan masyarakat serta kesempatan berusaha.

Disamping itu keberadaan industri tersebut juga akan meningkatkan kemampuan ekonomi wilayah yang bersangkutan. Bila ditinjau dari aspek sosial, keberadaan suatu industri dalam suatu wilayah akan menyebabkan terjadinya pergeseran-pergeseran di dalam masyarakat wilayah yang bersangkutan seperti perubahan pola pikir dan tata cara kehidupan lainnya. Menurut Djadjadiningrat dalam Siska (2013) dampak positif dari kegiatan pertambangan, selain merupakan sumber pendapatan asli daerah dan sumber devisa negara juga memberikan peran dalam membangun daerah di Indonesia, yaitu dengan terbukanya jalan didaerah yang terisolasi akibat adanya kegiatan pertambangan. Selain itu adanya kegiatan pertambangan akan membuka lapangan pekerjaan bagi masyarakat didaerah pertambangan tersebut. Basuki (2007a) telah meneliti dampak pembukaan wilayah pertambangan terhadap kondisi sosial ekonomi masyarakat di Kecamatan Lahei Kabupaten Barito Utara, 
Jurnal Progres Ekonomi Pembangunan (JPEP)

Volume 6, Nomor 2. Tahun 2021

Page: 110 - 122

http://ojs.uho.ac.id/index.php/JPEP

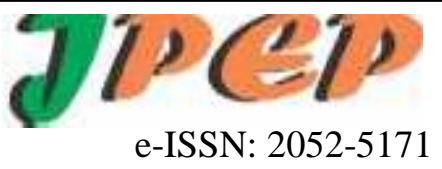

menunjukkan bahwa keberadaan industry pertambangan menjadi lahan pekerjaan baru untuk masyarakat serta dapat menumbuhkan pendapatan dan tingkat kesejahteraan rakyat di sekitarnya.

\section{Kerangka Konseptual}

Penyerapan tenaga kerja (Y) berdasarkan teori Undang-Undang Nomor 13 Tahun 2003 tentang Tenaga Kerja memberikan pengertian tentang tenaga kerja yang terdapat dalam Pasal 1 ayat 2 bahwa tenaga kerja yaitu setiap orang yang mampu melakukan pekerjaan guna menghasilkan barang dan/atau jasa baik untuk memenuhi kebutuhan sendiri maupun untuk masyarakat. Penyerapan tenaga kerja merupakan penduduk yang mampu bekerja dalam usia kerja (15-64 tahun) yang terdiri dari orang yang mencari kerja, punya pekerjaan namun sementara tidak bekerja atau menganggur. (Kuncoro, 2012, dan Putra, 2012).

Sedangkan Menurut undang-undang No 13 Tahun 2003 tentang ketenagakerjaan, tenaga kerja adalah setiap orang yang mampu melakukan pekerjaan guna menghasilkan barang dan jasa baik untuk memenuhi kebutuhan sendiri maupun untuk masyarakat. Pandangan mikro merupakan pandangan yang tidak hanya menyumbangkan potensi kerja namun dengan kerja mampu menerima imbalan berupa barang atau uang. Sedangkan secara makro adalah setiap orang yang mampu memenuhi kebutuhan masyakarat sebagai upaya dalam menghasilkan barang dan jasa (Mankiw, 2010).

Penyerapan tenaga kerja yang dilakukan merupakan jumlah tenaga kerja yang diserap dalam usaha tertentu. Namun kemampuan penyerapan akan berbeda satu unit usaha dengan usaha lainnya karena kemampuan unit usaha yang berbeda-beda. (Indayati, $2010 \mathrm{dkk}$ ). Faktor pembentuk variabel penyerapan tenaga kerja yang menjadi landasan pengembangan alat ukur dalam penelitian ini berasal dari konsep yang dikemukakan oleh Barthos (1999), yaitu; 1) tenaga kerja fisik dan 2) tenaga kerja berdasarkan pikiran. Peneliti mecoba mengilustrasikan kerangka konsep dasar pengujian dari ketiga variabel tersebut untuk melihat dampak antara variabel yang ditunjukkan pada Gambar 1 sebagai berikut:

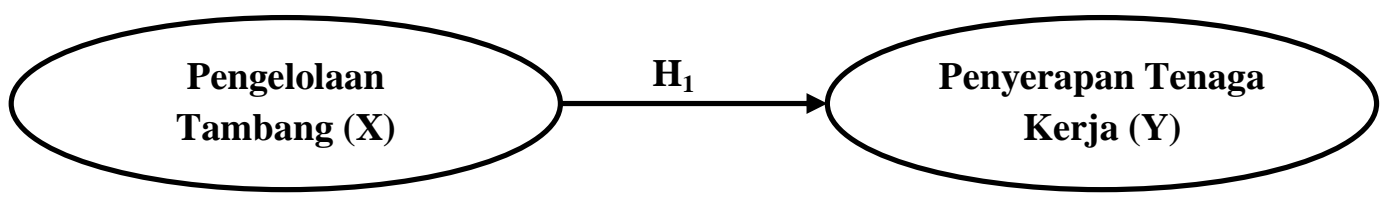

\section{Gambar 3.1 Kerangka Konseptual}

\section{Hipotesis Penelitian}

Berdasarkan kerangka konseptual penelitian yang telah dikemukakan sebelumnya, maka hipotesis penelitia adalah Pengelolaan pertambangan nikel berpengaruh signifikan terhadap penyerapan tenaga kerja lokal di Kabupaten Konawe Utara.

\section{METODE PENELITIAN}

\section{Populasi}

Populasi dalam penelitian ini adalah seluruh karyawan tetap di tambang nikel di Kabupaten Konawe Utara yang berjumlah 126 orang karyawan.

\section{Sampel}

Jumlah sampel minimal yang akan diambil, dihitung dengan menggunakan rumus Slovin (Husein, 2007):

$$
n=\frac{N}{1+N \cdot e^{2}}
$$

keterangan :

$\mathrm{n}=$ Jumlah sampel keseluruhan

$\mathrm{N}=$ besar populasi 
$\mathrm{e}=$ Persen kelonggaran ketidak telitian karena kesalahan pengambilan sampel yang masih dapat ditolerir.

Dari jumlah populasi tersebut dengan tingkat kelonggaran ketidaktelitian sebesar 5\% maka dengan menggunakan rumus diatas diperoleh sampel sebesar :

$n=\frac{126}{126(0,05)^{2}+1}$

$n=\frac{126}{1,315}$

$=95,81=96($ pembulatan$)$

\section{Metode Pengumpulan Data}

Metode yang dilakukan dalam pengumpulan data pada penelitian ini adalah (a) Kuesioner, yaitu daftar yang berisi pertanyaan-pertanyaan yang akan dijawab responden. (b) Dokumentasi, yaitu mengumpulkan dokumen-dokumen yang berkaitan dengan budaya organisasi, gaya kepemimpinan, kepuasan kerja dan kinerja karyawan.

\section{Uji Validitas}

Validitas merupakan suatu ukuran yang menunjukkan kevalidan atau kesahihan suatu instrumen. Instrumen dikatakan valid jika instrument tersebut dapat digunakan untuk mengukur apa yang hendak diukur (Sugiyono, 2006). Kriteria yang digunakan untuk uji validitas adalah apabila nilai $r \geq 0,30$ atau sig $<0,05$ dinyatakan valid. Sebaliknya apabila nilai $r \leq 0,30$ atau sig $>0,05$ dinyatakan invalid.

\section{Uji Reabilitas}

Uji reabilitas digunakan untuk mengetahui konsistensi alat ukur, apakah alat pengukur yang digunakan dapat diandalkan dan konsisten jika pengukuran tersebut diulang. Uji reabilitas ini didasarkan pada ketentuan koefisien korelasi Spearman-Brown bahwa apabila nilai croambach alpha > 0,60 maka dikatakan reliable.

\section{Metode Analisis Data}

Metode yang digunakan analisis data yang digunakan yaitu analisis regresi linear sederhana dengan bantuan softwere SPSS versi 23 dengan persamaan sebagai berikut: $\mathrm{Y}=\alpha+\beta 1 \mathrm{X}+e$

$$
\begin{array}{lll}
\text { Dimana: } & \mathrm{Y} & =\text { Penyerapan Tenaga Kerja } \\
\alpha & =\text { konstanta } \\
\beta_{1} & =\text { koefisien regresi } \\
\mathrm{X}_{1}, \mathrm{X}_{2}, \mathrm{X}_{3}, \mathrm{X}_{4} & =\text { Variabel independen } \\
\mathrm{X} & =\text { Pengelolaan Tambang Nikel } \\
\mathrm{e} & =\text { error }
\end{array}
$$

\section{Uji Faktor Kaiser - Meiyer - Olkin (KMO)}

Uji KMO dilakukan untuk mengetahui apakah faktor-faktor dalam penelitian valid atau tidak. Menurut Gozali (2009), angka KMO dan Barlette's Test harus di atas (0,5). Ketentuan tersebut didasarkan pada kriteria:

1) Jika probabilitas (sig) $<0,05$ maka variabel penelitian tidak dapat dianalisis lebih lanjut.

2) Jika probabilitas (sig) $>0,05$ maka variabel penelitian dapat dianalisis lebih lanjut.

\subsection{Uji Koefisien Determinasi $\mathbf{R}^{2}$}


Jurnal Progres Ekonomi Pembangunan (JPEP)

Volume 6, Nomor 2. Tahun 2021

Page: 110 - 122

http://ojs.uho.ac.id/index.php/JPEP

Koefisien determinasi $\left(\mathrm{R}^{2}\right)$ digunakan untuk mengukur tingkat kemampuan model dalam menerangkan variasi pada variabel dependen (Ghazali, 2011). Nilai $\mathrm{R}^{2}$ yang mendekati nol diartikan variabel independen dalam menjelaskan variabel dependen terbatas, sebaliknya jika nilai $\mathrm{R}^{2}$ mendekati satu berarti variabel independen memberikan hampir semua informasi yang diperlukan untuk memprediksi variabel dependen (Ghazali, 2011). Koefisien determinasi $\left(\mathrm{R}^{2}\right)$ merupakan suatu ukuran yang penting dalam regresi, karena dapat menginformasikan baik tidaknya model regresi yang terestimasi.

\section{Uji Signifikan Parsial (Uji_t)}

Uji t dilakukan untuk menguji pengaruh variabel-variabel bebas secara parsial terhadap variabel terikat (Hair et al., 2010). Pengujian hipotesis dalam riset ini bertujuan untuk menjawab apakah hipotesis yang diajukan dalam penelitian ini diterima atau ditolak. Taraf signifikasi estimasi parameter dalam pengujian hipotesis ditetapkan sebesar 95\% atau a $=0,05$. Dengan demikian pengujian hipotesis didasarkan atas nilai probabilitas dengan ketentuan sebagai berikut:

- Apabila $\rho<\mathrm{a}=0,05$, maka hipotesis yang diajukan dalam penelitian ini diterima artinya terdapat pengaruh signifikan antara variabel bebas terhadap variabel terikat.

- Apabila $\rho>\mathrm{a}=0,05$, hipotesis yang diajukan dalam penelitian ini ditolak artinya tidak terdapat pengaruh signifikan antara variabel bebas terhadap variabel terikat.

\section{HASIL PENELITIAN DAN PEMBAHASAN}

\section{Deskripsi Variabel Pengelolaan Tambang Nikel (X1)}

Menurut UU 4/2009 tentang Pertambangan Mineral dan Batubara Izin Usaha Pertambangan (IUP) adalah izin untuk melaksanakan usaha pertambangan, yang dapat diberikan kepada badan usaha, koperasi ataupun perorangan.” Pengelolaan tambang diukur dengan 10 item pertanyaan. Rekapitulasi jawaban responden terhadap pengelolaan tambang diuraikan sebagai berikut:

Tabel 1

Deskripsi Jawaban Terhadap Variabel Pengelolaan Tambang Nikel (X)

\begin{tabular}{|c|c|c|c|c|c|c|c|c|c|c|c|}
\hline \multirow{3}{*}{$\begin{array}{l}\text { Item } \\
\text { Butir }\end{array}$} & \multicolumn{10}{|c|}{ Frekuensi (f) dan Persentase (\%) Jawaban Responden } & \multirow[t]{3}{*}{$\begin{array}{l}\text { Rerata } \\
\text { (Mean) }\end{array}$} \\
\hline & \multicolumn{2}{|c|}{ STS (1) } & \multicolumn{2}{|c|}{ TS (2) } & \multicolumn{2}{|c|}{$\mathbf{N}(3)$} & \multicolumn{2}{|c|}{ S (4) } & \multicolumn{2}{|c|}{ SS (5) } & \\
\hline & $\mathbf{F}$ & $\%$ & $\mathbf{F}$ & $\%$ & $\mathbf{F}$ & $\%$ & f & $\%$ & f & $\%$ & \\
\hline $\mathrm{X}_{.1 .1}$ & 1 & 1,00 & 1 & 1,00 & 9 & 9,40 & 55 & 57,3 & 30 & 31,2 & 4.17 \\
\hline $\mathrm{X}_{.1 .2}$ & 1 & 1,00 & 1 & 1,00 & 9 & 9,40 & 64 & 66,7 & 21 & 21,9 & 4.07 \\
\hline \multicolumn{11}{|c|}{ Rerata Teknik Pertambangan Yang Tepat $\left(X_{.1}\right)$} & 4.12 \\
\hline $\mathrm{X}_{.2 .1}$ & 1 & 1,00 & 2 & 2,10 & 7 & 7,30 & 59 & 61,5 & 27 & 28,1 & 4.14 \\
\hline $\mathrm{X}_{.2 .2}$ & 1 & 1,00 & 1 & 1,00 & 3 & 3,10 & 68 & 70,8 & 23 & 24,0 & 4.16 \\
\hline \multicolumn{11}{|c|}{ Rerata Peduli Lingkungan $\left(X_{.2}\right)$} & 4.15 \\
\hline $\mathrm{X}_{.3 .1}$ & 0 & 0,00 & 2 & 2,10 & 5 & 5,20 & 63 & 65,6 & 26 & 27,1 & 4.18 \\
\hline $\mathrm{X}_{3.2}$ & 1 & 1,00 & 1 & 1,00 & 7 & 7.30 & 58 & 60.4 & 29 & 30.2 & 4.18 \\
\hline \multicolumn{11}{|c|}{ Rerata Peduli Kesehatan dan Keselamatan Kerja $\left(X_{.3}\right)$} & 4.18 \\
\hline $\mathrm{X}_{.4 .1}$ & 1 & 1,00 & 1 & 1,00 & 9 & 9,4 & 60 & 62,5 & 25 & 26,0 & 4.11 \\
\hline $\mathrm{X}_{.4 .2}$ & 0 & 0,00 & 1 & 1,00 & 9 & 9,4 & 54 & 56,2 & 32 & 33,3 & 4.22 \\
\hline \multicolumn{11}{|c|}{ Rerata Prinsip Konservasi $\left(\mathbf{X}_{.4}\right)$} & 4.17 \\
\hline $\mathrm{X}_{.5 .1}$ & 1 & 1,00 & 0 & 0,00 & 10 & 10,4 & 54 & 56,2 & 31 & 32,2 & 4.19 \\
\hline $\mathrm{X}_{.5 .2}$ & 0 & 0,00 & 1 & 1,00 & 14 & 14,6 & 51 & 53,1 & 30 & 31,2 & 4.15 \\
\hline \multicolumn{11}{|c|}{ Rerata Mempunyai Nilai Tambah $\left(\mathbf{X}_{.5}\right)$} & 4.17 \\
\hline \multicolumn{11}{|c|}{ Rerata Variabel Pengelolaan Tambang Nikel (X) } & 4.16 \\
\hline
\end{tabular}

\section{Sumber: Data Primer (Kuisioner) diolah, tahun 2021}

Berdasarkan rekapitulasi pernyataan atas variabel pengelolaan tambang nikel di Kabupaten Konawe Utara, seperti yang disajikan pada Tabel 1 di atas, menunjukkan bahwa deskripsi jawaban responden secara keseluruhan tentang pengelolaan tambang menyatakan setuju/baik dengan nilai rerata 4,16, karena berada pada interval $(3,41-4,2)$. Artinya bahwa mayoritas responden menyatakan 
Jurnal Progres Ekonomi Pembangunan (JPEP)

Volume 6, Nomor 2. Tahun 2021

Page: 110 - 122

http://ojs.uho.ac.id/index.php/JPEP

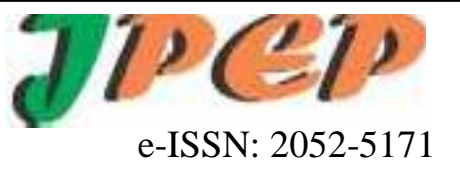

secara keseluruhan mengenai pengelolaan tambang nikel adalah sebagai hasil dalam meningkatkan penyerapan tenaga kerja.

\section{Deskripsi Variabel Peyerapan Tenaga Kerja (Y)}

Menurut Putra, (2012) penyerapan tenaga kerja merupakan penduduk yang mampu bekerja dalam usia kerja (15-64 tahun) yang terdiri dari orang yang mencari kerja, punya pekerjaan namun sementara tidak bekerja atau menganggur. Rekapitulasi jawaban responden terhadap penyerapan tenaga kerja diuraikan sebagai berikut:

Tabel 2

Deskripsi Jawaban Terhadap Variabel Penyerapan Tenaga Kerja (Y)

\begin{tabular}{|c|c|c|c|c|c|c|c|c|c|c|c|}
\hline \multirow{3}{*}{$\begin{array}{l}\text { Item } \\
\text { Butir }\end{array}$} & \multicolumn{10}{|c|}{ Frekuensi (f) dan Persentase (\%) Jawaban Responden } & \multirow[t]{3}{*}{$\begin{array}{l}\text { Rerata } \\
\text { (Mean) }\end{array}$} \\
\hline & \multicolumn{2}{|c|}{ STS (1) } & \multicolumn{2}{|c|}{ TS (2) } & \multicolumn{2}{|c|}{$\mathbf{N}(3)$} & \multicolumn{2}{|c|}{$S(4)$} & \multicolumn{2}{|c|}{ SS (5) } & \\
\hline & $\mathbf{f}$ & $\%$ & $\mathbf{F}$ & $\%$ & $\mathbf{F}$ & $\%$ & $\mathbf{f}$ & $\%$ & $\mathbf{f}$ & $\%$ & \\
\hline $\mathrm{Y}_{.1 .1}$ & 1 & 1,00 & 0 & 0,00 & 9 & 9,40 & 67 & 69,8 & 19 & 19,8 & 4.07 \\
\hline$Y_{.1 .2}$ & 1 & 1,00 & 2 & 2,10 & 8 & 8,3 & 58 & 60,4 & 27 & 28,1 & 4.12 \\
\hline \multicolumn{11}{|c|}{ Rerata Tenaga Kerja Fisik $\left(\mathbf{Y}_{.1}\right)$} & 4.10 \\
\hline$Y_{.2 .1}$ & 0 & 0,00 & 0 & 0,00 & 10 & 10,4 & 57 & 59,4 & 29 & 30,2 & 4.20 \\
\hline$Y_{.2 .2}$ & 0 & 0,00 & 0 & 0,00 & 10 & 10,4 & 60 & 62,5 & 26 & 27,1 & 4.17 \\
\hline \multicolumn{11}{|c|}{ Rerata Tenaga Kerja Pikiran $\left(Y_{.2}\right)$} & 4.19 \\
\hline \multicolumn{11}{|c|}{ Rerata Variabel Penyerapan Tenaga Kerja (Y) } & 4.14 \\
\hline
\end{tabular}

Sumber: Data Primer (kuisioner) diolah, tahun 2021

Berdasarkan rekapitulasi pernyataan atas variabel penyerapan tenaga kerja di Kabupaten Konawe Utara, seperti yang disajikan pada Tabel 2 di atas, menunjukkan bahwa deskripsi jawaban responden secara keseluruhan tentang penyerapan tenaga kerja menyatakan setuju/baik dengan nilai rerata 4,14, karena berada pada interval $(3,41-4,2)$. Artinya bahwa mayoritas responden menyatakan secara keseluruhan mengenai penyerapan tenaga kerja adalah sebagai hasil dalam meningkatkan penyerapan tenaga kerja.

\section{Uji Validitas}

Kriteria yang digunakan untuk uji validitas adalah apabila nilai $r \geq 0,30$ atau sig $<0,05$ dinyatakan valid. Sebaliknya apabila nilai $r \leq 0,30$ atau $\mathrm{sig}>0,05$ dinyatakan invalid.

\section{Tabel 3}

Uji Validitas Variabel

\begin{tabular}{|c|c|c|c|c|}
\hline No & Variabel & No. Indikator & Koefisien Korelasi & Keterangan \\
\hline \multirow{10}{*}{1} & \multirow{10}{*}{$\begin{array}{c}\text { Pengelolaan Tambang } \\
\text { Nikel (X) }\end{array}$} & X.1.1 & 0,702 & Valid \\
\hline & & X.1.2 & 0,720 & Valid \\
\hline & & X.2.1 & 0,662 & Valid \\
\hline & & X.2.2 & 0,660 & Valid \\
\hline & & X.3.1 & 0,662 & Valid \\
\hline & & X.3.2 & 0,700 & Valid \\
\hline & & X.4.1 & 0,716 & Valid \\
\hline & & X.4.2 & 0,746 & Valid \\
\hline & & X.5.1 & 0,763 & Valid \\
\hline & & X.5.2 & 0,687 & Valid \\
\hline \multirow{4}{*}{2} & \multirow{4}{*}{$\begin{array}{c}\text { Penyerapan Tenaga } \\
\text { Kerja (Y) }\end{array}$} & Y.1.1 & 0,681 & Valid \\
\hline & & Y.1.2 & 0,771 & Valid \\
\hline & & Y.2.1 & 0,796 & Valid \\
\hline & & Y.2.2 & 0,722 & Valid \\
\hline
\end{tabular}

Sumber: Hasil output SPSS 23, data diolah (2021) 
Jurnal Progres Ekonomi Pembangunan (JPEP)

Volume 6, Nomor 2. Tahun 2021

Page: 110 - 122

http://ojs.uho.ac.id/index.php/JPEP

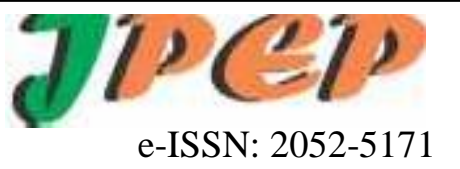

\section{Uji Reliabel}

Uji reabilitas ini didasarkan pada ketentuan koefisien korelasi Spearman-Brown bahwa apabila nilai croambach alpha > 0,60 maka dikatakan reliabel.

Tabel 4

Uji Reliabilitas Variabel

\begin{tabular}{cccc}
\hline No & Variabel & Cronbach's Alpha & Keterangan \\
\hline 1 & Pengelolaan Tambang Nikel (X) & 0,769 & Reliabel \\
3 & Penyerapan Tenaga Kerja (Y) & 0,795 & Reliabel \\
\hline
\end{tabular}

Sumber: Hasil output SPSS 23, data diolah (2021)

Tabel 4 menunjukkan bahwa nilai Cronbach's Alpha seluruh variabel Pengelolaan Tambang

Nikel (X) sebesar (0.769) dan variabel Penyerapan Tenaga Kerja (Y) Sebesar $(0,705)$ hal ini menunjukkan konsisten karena nilai Cronbach's Alpha lebih besar dari 0,60 atau dikatakan seluruh variabel dalam penelitian ini Realiabel.

\section{Uji Faktor Loading Variabel}

Uji KMO dilakukan untuk mengetahui apakah faktor-faktor dalam penelitian valid atau tidak. Menurut Imam Gozali (2009), angka KMO dan Barlette's Test harus di atas (0,5). Ketentuan tersebut didasarkan pada kriteria:

Tabel 5

Loading Faktor dan Mean Variabel Penelitian

\begin{tabular}{|c|c|c|c|c|c|}
\hline No & Variabel & No. Indikator & Mean & Loading Faktor & Keterangan \\
\hline \multirow{10}{*}{1} & \multirow{10}{*}{$\begin{array}{c}\text { Pengelolaan } \\
\text { Tambang Nikel (X) }\end{array}$} & $\mathrm{X} 1.1 .1$ & \multirow{2}{*}{4.12} & 0,730 & Valid \\
\hline & & $\mathrm{X} 1.1 .2$ & & 0,690 & Valid \\
\hline & & $\mathrm{X} 1.2 .1$ & \multirow{2}{*}{4.15} & 0,522 & Valid \\
\hline & & $\mathrm{X} 1.2 .2$ & & 0,598 & Valid \\
\hline & & $\mathrm{X} 1.3 .1$ & \multirow{2}{*}{4.18} & 0,535 & Valid \\
\hline & & $\mathrm{X} 1.3 .2$ & & 0,504 & Valid \\
\hline & & $\mathrm{X} 1.4 .1$ & \multirow{2}{*}{4.17} & 0,513 & Valid \\
\hline & & $\mathrm{X} 1.4 .2$ & & 0,776 & Valid \\
\hline & & $\mathrm{X} 1.5 .1$ & & 0,612 & Valid \\
\hline & & $\mathrm{X} 1.5 .2$ & 4.17 & 0,665 & Valid \\
\hline \multirow{4}{*}{2} & & Y2.1.1 & \multirow[b]{2}{*}{4.10} & 0,443 & Tidak Valid \\
\hline & Penyerapan Tenaga & $\mathrm{Y} 2.1 .2$ & & 0,566 & Valid \\
\hline & Kerja (Y2) & Y2.2.1 & \multirow{2}{*}{4.19} & 0,664 & Valid \\
\hline & & $\mathrm{Y} 2.2 .2$ & & 0,545 & Valid \\
\hline
\end{tabular}

Sumber: Hasil output SPSS 23, data diolah (2021)

Berdasarkan Tabel 5.8 diatas menunjukkan bahwa variabel Pengelolaan Tambang Nikel (X) yang terdiri dari 10 indikator memiliki nilai loading faktor diatas 0,5 sehingga dapat dikatakan valid. Kemudian pada variabel sosial ekonomi (Y1) yang terdiri dari 8 indikator memiliki nilai loading faktor terdiri dari indicator Y1.1.2, Y1.3.1, Y1.4.1 dan Y1.4.2 atau diatas 0,5 sehingga di katakan valid, sedangkan indicator Y1.1.1, Y1.2.1, Y1.2.2 dan Y1.3.2 atau berada dibawah 0,5 sehingga dikatakan tidak valid. Kemudian pada variabel penyerapan tenaga kerja (Y2) yang terdiri dari 4 indikator memiliki nilai loadiang faktor terdiri dari indicator Y2.1.2, Y2.2.1 dan Y2.2.2 atau diatas 0,5 sehingga di katakan valid, sedangkan indicator Y2.1.1 atau berada dibawah 0,5 sehingga dikatakan tidak valid.

\section{Uji Koefisien Determinasi $\left(\mathbf{R}^{2}\right)$}

Pada model regresi berganda, koefisien determinasi (R2) digunakan untuk mengukur tingkat kemampuan model dalam menerangkan variasi pada variabel dependen (Ghazali, 2011). Nilai $\mathrm{R}^{2}$ yang mendekati nol diartikan variabel independen dalam menjelaskan variabel dependen terbatas, 
Jurnal Progres Ekonomi Pembangunan (JPEP)

Volume 6, Nomor 2. Tahun 2021

Page: 110 - 122

http://ojs.uho.ac.id/index.php/JPEP

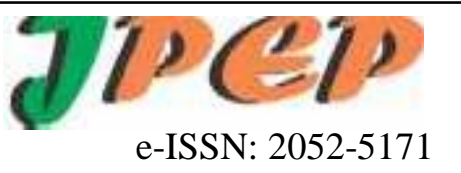

sebaliknya jika nilai $\mathrm{R}^{2}$ mendekati satu berarti variabel independen memberikan hampir semua informasi yang diperlukan untuk memprediksi variabel dependen (Ghazali, 2011).

Tabel 6

Pengujian Koefisien Determinasi $\mathbf{R}^{2}$ Model Summary

\begin{tabular}{cccccc}
\hline \multicolumn{7}{c}{ Variabel } & Model & $\mathbf{R}$ & R Square & $\begin{array}{c}\text { Adjusted R } \\
\text { Square }\end{array}$ & $\begin{array}{c}\text { Std. Error of the } \\
\text { Estimate }\end{array}$ \\
\hline $\begin{array}{l}\text { Dampak pengelolaan tambang } \\
\text { nikel terhadap penyerapan } \\
\text { tenaga kerja }\end{array}$ & 2 & $.572^{\mathrm{a}}$ & .327 & .320 & .39090 \\
\hline
\end{tabular}

Sumber: Hasil output SPSS 23, data diolah (2021)

Berdasarkan Tabel 6 di atas menunjukkan:

a. Nilai R (angka koefisien korelasi) sebesar 0,372 menunjukkan bahwa keeratan hubungan langsung antara pengelolaan tambang nikel terhadap sosial ekonomi adalah sebesar 0,372. Sedangkan nilai $R$ (angka koefisien korelasi) sebesar 0,572 menunjukkan bahwa keeratan hubungan langsung antara pengelolaan tambang nikel terhadap penyerapan tenaga kerja adalah sebesar 0,572.

\section{Uji Signifikan Parsial (Uji_t)}

Uji parsial digunakan untuk mengetahui pengaruh masing- masing variabel independen terhadap variabel dependen (Ghazali, 2013), yaitu dengan membandingkan masing-masing nilai t_statistik dari regresi dengan t-tabel dalam menolak atau menerima hipotesis. Model dikatakan signifikan jika nilai sig. $\mathrm{t} \leq \alpha$. Hasil pengujian parsial Uji_t coefficients dapat dilihat pada tabel 5.10:

Tabel 57

Hasil Pengujian Parsial Uji_t

\begin{tabular}{|c|c|c|c|c|c|c|}
\hline \multicolumn{7}{|c|}{ Coefficients ${ }^{\mathrm{a}}$} \\
\hline \multirow[b]{2}{*}{ Model } & & \multicolumn{2}{|c|}{ Unstandardized Coefficients } & $\begin{array}{c}\text { Standardized } \\
\text { Coefficients }\end{array}$ & \multirow[b]{2}{*}{$\mathrm{T}$} & \multirow[b]{2}{*}{ Sig. } \\
\hline & & $\mathrm{B}$ & Std. Error & Beta & & \\
\hline \multirow[t]{2}{*}{1} & (Constant) & 1.776 & .352 & & 5.046 & .000 \\
\hline & $X$ & .569 & .084 & .572 & 6.763 & .000 \\
\hline
\end{tabular}

Sumber: Hasil output SPSS 23, data diolah (2021) berikut:

Berdasarkan Tabel 5.11 hasil analisis regresi multivariate diperoleh persamaan sebagai

$$
\mathrm{Y}=\mathbf{0 , 5 7 2}(\mathrm{X})
$$

Variabel pengelolaan tambang nikel berpengaruh positif dan signifikan terhadap penyerapan tenaga kerja, yang dibuktikan dengan koefisen regresi bertanda positif sebesar 0,572 dan nilai signifikan sebesar 0,000 lebih kecil dari $\alpha=0,05$ atau $5 \%$.

\section{Pembahasan}

Pengelolaan tambang nikel berpengaruh positif dan signifikan terhadap penyerapan tenaga kerja di Kabupaten Konawe Utara. Hal ini dibuktikan dengan jawaban responden secara keseluruhan tentang pengelolaan tambang nikel menyatakan setuju/baik dengan nilai rerata 4,14 , karena berada pada interval $(3,41-4,2)$. Artinya bahwa mayoritas responden menyatakan secara keseluruhan mengenai pengelolaan tambang nikel adalah sebagai hasil dalam meningkatkan penyerapan tenaga kerja. Kemudian berdasarkan hasil uji parsial analisis regresi pengelolaan tambang nikel berpengaruh positif dan signifikan terhadap penyerapan tenaga kerja.

Kemudian hasil penelitian ini didukung dengan fakta di lapangan yang menunjukkan bahwa pengelolaan tambang nikel yang baik direfleksikan melalui penerapan teknik penambangan yang tepat, peduli lingkungan, peduli kesehatan dan keselamatan kerja, penerapan prinsip konservasi dan 
Jurnal Progres Ekonomi Pembangunan (JPEP)

Volume 6, Nomor 2. Tahun 2021

Page: 110 - 122

http://ojs.uho.ac.id/index.php/JPEP

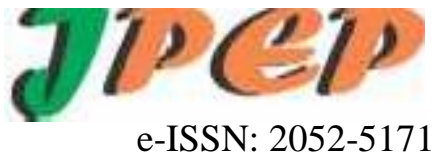

mempunyai nilai tambah, sehingga mempunyai kontribusi positif dan signifikan pada peningkatan penyerapan tenaga kerja. Kemudian fakta lapangan menunjukkan bahwa ketentuan bijih nikel sebagai salah satu sumber daya alam dalam industri pertambangan karena dipandang memberikan pendapatan asli daerah yang lebih tinggi sehingga dapat meningkatkan perekonomian dan pembangunan, serta menciptakan lapangan kerja bagi masyarakat lokal dan masyarakat luar lokasi penambangan.

Selanjutnya, dampak langsung dari keberadaan pabrik pengolahan nikel khususnya masyarakat sekitar penambangan Kabupaten Konawe Utara yang tidak memiliki pekerjaan tetap khususnya anak-anak remaja telah masuk sebagai pegawai tetap di pabrik pengolahan nikel tersebut. Hasil penelitian sesuai dengan landasan hukum tertinggi dalam penyelenggaraan pemerintahan di bidang pertambangan di negara ini adalah konstitusi Undang-Undang Dasar 1945, khususnya Pasal 33 ayat 3 dan ayat 2. Pasal 33 ayat 3 menyatakan, "Bumi dan air dan kekayaan alam yang terkandung di dalamnya dikuasai oleh Negara dan dipergunakan untuk sebesar-besar kemakmuran rakyat",

Sedangkan ayat 2 menyatakan, "Cabang-cabang produksi yang penting bagi Negara dan yang menguasai hajat hidup orang banyak dikuasai oleh Negara". Frase kunci dari kedua ayat ini dalam hal sistem pengelolaan pertambangan adalah "dikuasai oleh Negara" dan "untuk sebesar-besar kemakmuran rakyat". "Dikuasai" memiliki dimensi geopolitik bahwa negara harus memiliki kuasa (berdaulat) atas pengelolaan kekayaan alam yang ada, sedangkan "sebesar-besar" mengandung dimensi geo-ekonomi bahwa di dalam pengelolaannya harus ada maksimalisasi usaha (Utomo, 2010). Maka, terjemahannya di dalam sistem pengelolaan pertambangan seharusnya adalah kuasa pertambangan (mining rights) ada di tangan pemerintah sebagai wakil dari negara, dan dalam pelaksanaannya diserahkan kepada badan usaha milik negara (BUMN).

Penyerahan pelaksanaan kuasa pertambangan kepada BUMN adalah suatu keharusan karena BUMN sekaligus merepresentasikan bahwa penguasaan tetap berada di tangan Negara (dimensi geopolitik) dan dilakukan sesuai dengan prinsip usaha (dimensi geo-ekonomi). Menurut Saleng (2007), paradigma mengenai pemanfaatan sumberdaya alam lebih berorientasi pada sumber pendapatan ketimbang modal. Eksploitasi sumber daya alam hanya diarahkan untuk mendukung pertumbuhan ekonomi tanpa memperhatikan secara proposional kelestarian fungsi lingkungan hidup.

Hasil penelitian sesuai dengan penelitian yang dilakukan oleh Semuel Risal, DB. Paranoan, Suarta Djaja (2013), Nurlaela, Suharty Roslan, Bakri Yusuf dan Muhamad Masri (2020), Ceceng Selegi (2018), Meitha Suciyanti, Triswan Suseno dan Ridwan Saleh (2018), Herwin Eka Putra (2017), Diana Lestari (2016), Candra Mustika (2018), Zamzami; Candra Mustika; Jaya Kesuma Edy (2015), yang menyatakan bahwa pengelolaan tambang nikel berpengaruh positif dan signifikan terhadap penyerapan tenaga kerja.

\section{PENUTUP \\ Kesimpulan}

Berdasarkan hasil dan pembahasan di atas maka dapat disimpulkan bahwa pengelolaan tambang nikel berpengaruh positif dan signifikan terhadap penyerapan tenaga kerja di Kabupaten Konawe Utara. Artinya bahwa pengelolaan tambang nikel yang baik direfleksikan melalui penerapan teknik penambangan yang tepat, peduli lingkungan, peduli kesehatan dan keselamatan kerja, penerapan prinsip konservasi dan mempunyai nilai tambah, sehingga mempunyai dampak atau pengaruh yang signifikan dan positif pada peningkatan penyerapan tenaga kerja. Ketentuan bijih nikel sebagai salah satu sumber daya alam dalam industri pertambangan karena dipandang memberikan pendapatan asli daerah yang lebih tinggi sehingga dapat meningkatkan perekonomian dan pembangunan, serta menciptakan lapangan kerja bagi masyarakat lokal dan masyarakat luar lokasi penambangan.

\section{Saran}

Berdasarkan pada hasil dan kesimpulan penelitian ini, dapat dikemukakan saran-saran yang menjadi rekomendasi penelitian ini sebagai berikut: 
1. Bagi pemerintah daerah Kabupaten Konawe Utara lebih meningkatkan kualitas tenaga kerja lokal melalui berbagai pelatihan, sehingga tenaga kerja lokal yang terserap di sektor pertambangan tidak hanya menjadi tenaga kerja kasar., namun dapat diserap sebagai tenaga kerja ahli dalam aktivitas pertambangan di Kabupaten Konawe Utara.

2. Bagi penelitian selanjutnya sebaiknya dapat menambahkan keragaman hasil penelitian dan konsistensi penelitian dengan menguji kembali pada sampel yang lebih besar. Dan menambahkan variabel lain yang mempengaruhi penyerapan tenaga kerja, misalnya faktor upah, modal dan nilai produksi pada tambang nikel di Kabupaten Konawe Utara.

\section{DAFTAR PUSTAKA}

Barthos, Basir. (2004). Manajemen Sumber Daya Manusia Suatu Pendekatan Makro, Jakarta: Bumi Aksara.

Candra Mustika (2018) "pengaruh ekspor minyak mentah batu bara dan gas alam terhadap penyerapan tenaga kerja sektor pertambangan di Indonesia"

Ceceng Selegi (2018), "Dampak Aktivitas Pertambangan Nikel Terhadap Kondisi Sosial Ekonomi Masyarakat Di Kecamatan Tinanggea Kabupaten Konawe Selatan"

Diana Lestari (2016) "Dampak Investasi Sektor Pertambangan Terhadap Pertumbuhan Ekonomi dan Tenaga Kerja”

Firmanto, A., (2012), Pengendalian Degradasi Lingkungan di Sektor Pertambangan, Warta Minerba, Edisi 14 Hal. 4-9, Direktorat Jenderal Mineral dan Batubara, Jakarta

Gatot Supramono, (2012), Hukum Pertambangan Mineral dan Batu Bara di Indonesia, Jakarta, Rineka Cipta.

Ghozali, Imam. (2006). Aplikasi Analisis Multivariate Dengan Program SPSS. Cetakan Keempat. Semarang: Badan Penerbit Universitas Diponegoro.

Herwin Eka Putra (2017) "Dampak Pertambangan Batubara Terhadap Ekonomi dan Sosial Masyarakat Di Desa Tanjung Belit Kecamatan Jujuhan Kabupaten Bungo"

Husein Umar. (2007), Metode Penelitian Untuk Skripsi Dan Tesis Bisnis, Jakarta: PT. Raja Grafindo Persada

Indayati, Nurul, dkk. (2010). Pengaruh Keterlibatan Karyawan, Budaya Organisasi, dan Gaya Kepemimpinan terhadap Komitmen Organisasional dalam Meningkatkan Kinerja Karyawan. Terakreditasi SK. Dirjen Dikti no. 66b/Dikti/Kep/2011.

Kuncoro, Haryo. (2002), Upah Sistem Bagi Hasil dan Penyerapan Tenaga Kerja, Jurnal Ekonomi Pembangunan, Vol 7.

Latupono, S, (2005), Kajian Kerusakan Laingkungan Akibat Penambangan Pasir dan Batu di Desa Waeheru Kecamatan Teluk Ambon Baguala Kota Ambon, Tesis Pascasarjana Universitas Gajah Mada, Yogyakarta

Mankiw, N. Gregory. (2010). Makroekonomi. Jakarta: Erlangga.

Meitha Suciyanti, Triswan Suseno dan Ridwan Saleh (2018) "Analisis Dampak Kegiatan Pertambangan Tembaga Terhadap Perekonomian Provinsi Papua"

Nurlaela, Suharty Roslan, Bakri Yusuf dan Muhamad Masri (2020) "Dampak Pengelolaan Nikel terhadap Sosial Ekonomi Masyarakat Kondisi di Kecamatan Morosi Kabupaten Konawe"

Peratuan Pemerintah No 55 Tahun 2010 tentang Pembinaan dan Pengawasan Penyelenggaraan Pengelolaan Usaha Pertambangan Mineral dan Batubara 
Putra, Nusa. (2012). Metode Penelitian Kualitatif Pendidikan. Jakarta : Rajagrafindo Persada.

Saleng, Abrar. (2007). Hukum Pertambangan. Yogyakarta: UII Press,

Salim, H. (2012). Hukum Pertambangan Di Indonesia. Jakarta: Raja Grafindo Persada.

Semuel Risal, DB. Paranoan, Suarta Djaja (2013) "Analisis Dampak Kebijakan Pertambangan Terhadap Kehidupan Sosial Ekonomi Masyarakat di Kelurahan Makroman”

Siska, (2013). "Dampak Industri Batubara Terhadap Sosial Ekonomi Masyarakat di sekitar Desa Jembayan Kecamatan Loa Kulu Kabupaten Kutai Kertanegara”. eJournal Administrasi Negara $1(2): 473-493$.

Sugiyono. (2006). Metode Penelitian Kuantitatif Kualitatif dan R\&D. Bandung:

Sumarsono, Sonny (2003), Ekonomi Manajemen Sumber Daya Manusia. Surabaya: Airlangga University Pers.

Todaro, M.P. dan Smith Stephen. C. (2003). Pembangunan Ekonomi di Dunia Ketiga. Edisi kedelapan. Jilid 2. Jakarta: Erlangga.

Undang - undang no 4 tahun 2009 tentang Pertambangan Mineral dan Batubara Izin Usaha Pertambangan

Undang-Undang No 32 tahun 2009 tentang Perlindungan dan pengelolaan lingkungan hidup.

Undang-Undang Nomor 13 Tahun 2003 tentang Tenaga Kerja.

Undang-Undang Nomor 32 tahun 2009 tentang Perlindungan dan Pengelolaan Lingkungan Hidup dan Keputusan Menteri Lingkungan Hidup.

Utomo, Dian. (2010). Kebijakan Pelayanan Administrasi Terpadu Kecamatan (PATEN).Direktorat Jendral Pemerintahan Umum, Kementrian Dalam Negeri Indonesia

Zamzami; Candra Mustika; Jaya Kesuma Edy (2015) "Analisis Pengaruh Foreign direct investment terhadap penyerapan tenaga kerja di sektor pertanian,manufaktur dan pertambangan di Indonesia" 